\title{
Differential responses of ribulose-1,5-bisphosphate carboxylase/oxygenase activities of two Vigna unguiculata cultivars to salt stress
}

\author{
Maria Erivalda Farias de Aragão ${ }^{1 *}$, Marjorie Moreira Guedes ${ }^{2}$, Maria de Lourdes Oliveira Otoch ${ }^{1}$, Maria \\ Izabel Florindo Guedes ${ }^{1}$, Dirce Fernandes de Melo $^{2}$ and Maria da Guia Silva Lima ${ }^{2}$ \\ ${ }^{1}$ Departamento de Biologia,Universidade Estadual do Ceará (UECE), CEP 60455-440, Fortaleza, CE, Brasil; ${ }^{2}$ Departamento de Bioquimica \\ e Biologia Molecular, Universidade Federal do Ceará, Fortaleza, CE, Brasil. *Corresponding author: mefaragao@uece.br \\ Received: 06/03/2005, Accepted: 17/06/2005
}

Vita 3 and Vita 5 are two Vigna unguiculata cultivars that differ in their capacities for survival in saline environments; Vita 3 is more tolerant and Vita 5 more sensitive. Both cultivars were submitted to salt stress with $0.1 \mathrm{M} \mathrm{NaCl}$. After 8 days, root and shoot growth from both cultivars was reduced but reduction was more pronounced in Vita 5. Furthermore, leaf area was also reduced in this cultivar. Chlorophyll content and chlorophyll fluorescence parameters were not affected by salt stress, but the specific activities of ribulose-1,5-bisphosphate carboxylase/oxygenase (Rubisco) decreased in Vita 3 and increased in Vita 5. The use of immunological techniques also revealed that the Rubisco content from Vita 3 decreased while that of Vita 5 increased. The discussion of these results is aimed at reaching a better understanding of the differences between these cultivars in relation to salt stress.

Key words: Rubisco, photosynthesis, salt stress, Vigna unguiculata.

Respostas diferenciais das atividades de ribulose-1,5-bisfosfato carboxilase/oxigenase de duas cultivares de Vigna unguiculata ao estresse salino: Vita 3 e Vita 5 são cultivares de Vigna unguiculata que diferem na capacidade de sobrevivência em ambiente salino: Vita 3 é mais tolerante e, Vita 5, mais suscetível. Ambas as cultivares foram submetidas a um tratamento salino com $\mathrm{NaCl}$ 0,1 M. Após 8 dias da germinação, o crescimento das raízes e das partes aéreas foram reduzidas, sendo a redução mais acentuada na cultivar Vita 5. Além do mais, houve uma diminuição na sua área foliar. Os conteúdos de clorofila, bem como seus parâmetros de fluorescência não foram afetados pelo estresse salino, mas as atividades da ribulose-1,5bisfosfato carboxilase/oxigenase (Rubisco) diminuiu na Vita 3 e aumentou na Vita 5. Uma abordagem imunológica mostrou que o conteúdo da proteína Rubisco diminuiu para a cultivar Vita 3 e aumentou para a cultivar Vita 5. Esses resultados são discutidos para obter melhor entendimento das diferenças entre essas cultivares em relação ao estresse salino.

Palavras-chaves: estresse salino, fotossíntese, Rubisco, Vigna unguiculata.

\section{INTRODUCTION}

Photosynthesis is strongly affected by salinity, mainly because it reduces stomatal conductivity, causing a decrease in the intercellular level of $\mathrm{CO}_{2}$ (Downton et al., 1985, Seeman and Critchley, 1985). However, the decrease in net photosynthesis is also due to nonstomatal factors, which inhibit electron transport and photophosphorylation activity (Keck and Boyer, 1974; Ortiz-Lopez et al., 1991). Another negative aspect of salinity on photosynthetic activity is the fact that osmotic stress modifies the permeability of the chloroplast envelope and affects the activity of stroma enzymes (Kaiser and Heber, 1981). Presently, it is known

Abreviations: $\mathrm{EDTA}=$ ethylene diamine tetra-acetic acid; DMSO $=$ dimethyl sulfoxide; $\mathrm{DTT}=$ dithiothreitol; $\mathrm{F}_{\mathrm{o}}=$ dark fluorescence level; $\mathrm{F}_{\mathrm{m}}=$ maximum fluorescence level; $\mathrm{F}_{\mathrm{v}}=$ variable fluorescence; $\mathrm{NADH}=$ reduced nicotinamide dinucleotide; $\mathrm{PMSF}=$ phenylmethylsulfonyl fluoride; $\mathrm{PVP}=$ polyvinylpyrrolidone; Rubisco $=$ Ribulose-1,5-bisphosphate carboxylase/oxygenase; Temed = N',N,N, tetramethylenediamine. 
that these enzymes are inhibited in vitro by $\mathrm{NaCl}$ (Greenway and Osmond, 1972; Incharoensakdi et al., 1986).

A key enzyme for carbon photosynthetic reduction in plants, ribulose-1,5-bisphosphate carboxylase/oxygenase (Rubisco, E.C. 4.1.1.39), is a stromal protein. In $\mathrm{C}_{3}$ plants, this enzyme is responsible for the primary step in $\mathrm{CO}_{2}$ fixation and its carboxylating capacity can be the limiting factor in photosynthesis (Woodrow and Berry, 1988). Since Rubisco is inhibited in vitro by high concentrations of salts, and considering that the cytosol of salt-treated plants contains a high concentration of $\mathrm{NaCl}$ (Flowers et al., 1977), the in vivo Rubisco activity may be similarly affected by salt. However, in the salt tolerant alga Dunaliella parva, Rubisco activity doubled when cultivated in a medium containing high salt concentration (Gimmler et al., 1984). Rubisco content in leaves is proportional to the photosynthetic rate (Woodrow and Berry, 1988) and an increase in its content should induce a positive adjustment of the plant to an adverse environment. Indeed, the adaptation of the halophyte species Tamarix to salinity is associated with increased Rubisco content and solutes that stabilize the enzyme (Solomon et al., 1994.). Nevertheless, Rubisco may undergo stress-induced modifications that influence its activity and degradation rate (Ferreira and Teixeira, 1992). Therefore, the degradation of Rubisco is a factor that regulates photosynthetic rate and so it would be necessary to produce new enzyme copies to fully reestablish the photosynthetic function (Desimone et al., 1996).

The glicophyte species, Vigna unguiculata, possesses 2 cultivars that differ in their degree of salt tolerance: Vita 3 is considered to be more resistant than Vita 5 (Guimarães, 1988). With the aim of understanding the constitutive biochemical factors of such diversity, the activity of Rubisco and chlorophyll fluorescence of these two cultivars, grown in the absence and presence of $0.1 \mathrm{M} \mathrm{NaCl}$, were analyzed in the present study. In order to better understand the role of Rubisco in the mechanism of tolerance/susceptibility to salinity, this enzyme was purified and specific antibodies produced as essential tools for the quantification of Rubisco.

\section{MATERIAL AND METHODS}

Plant material: Seeds of Vigna unguiculata, cv Vita 3 and Vita 5 were treated with $0.4 \%$ sodium hipochloride for 10 min, rinsed with distilled water and germinated on paperfilter soaked with distilled water, for 4 days. Seedlings were transferred to a hydroponic system in a greenhouse and maintained under natural irradiance, a $12 \mathrm{~h}$ photoperiod and a $35 / 25^{\circ} \mathrm{C}$ day/night temperature. The hydroponic system was aerated and contained: $5.6 \mathrm{mM} \mathrm{Ca}\left(\mathrm{NO}_{3}\right)_{2}, 2 \mathrm{mM} \mathrm{KNO}_{3}$, $2 \mathrm{mM} \mathrm{KH}_{2} \mathrm{PO}_{4}, 2 \mathrm{mM} \mathrm{MgSO}_{4}, 0.1 \mathrm{mM}$ FeEDTA, $40.4 \mu \mathrm{M}$ $\mathrm{H}_{3} \mathrm{BO}_{3}, 7.5 \mu \mathrm{M} \mathrm{MnCl}_{2}, 0.2 \mu \mathrm{M} \mathrm{CuCl}_{2}, 0.05 \mu \mathrm{M} \mathrm{MoO}_{4}$ and $0.6 \mu \mathrm{M} \mathrm{ZnSO}_{4}$ made up in deionized $\mathrm{H}_{2} \mathrm{O}$ and a $\mathrm{pH}$ around 6.5. After 8 days of germination, the salt treatment was applied by addition of $0.1 \mathrm{M} \mathrm{NaCl}$ to the nutrient solution and plants were harvested 8 days later.

Growth parameters: Length and fresh weight of shoots and roots were measured. Dry matter was determined by drying at $85^{\circ} \mathrm{C}$ for $48 \mathrm{~h}$. Leaf area of detached leaves from Vita 3 and Vita 5 cultivars under control and salt conditions were measured using a LI-COR leaf area instrument.

Protein extraction: Leaves were macerated in a mortar with the extraction buffer (100 $\mathrm{mM}$ Tris/ $\mathrm{HCl}$ buffer, $\mathrm{pH}$ 8.0) containing $5 \mathrm{mM} \mathrm{Na}_{2}$ EDTA, $5 \mathrm{mM} \mathrm{MgCl}_{2}, 1 \mathrm{mM}$ PMSF, $1 \mathrm{mM}$ benzamidine and 10 g.L. $\mathrm{L}^{-1} \mathrm{PVP}-40$ ) in the proportion of 1:10 (w:v). The homogenate was then centrifuged at 30,000 $g_{\mathrm{n}}$ for $20 \mathrm{~min}$. The supernatant was loaded on a Sephadex G-25 column, previously equilibrated with $50 \mathrm{mM}$ Tris/HCl buffer (pH 7.6) containing $5 \mathrm{mM} \mathrm{MgCl}_{2}$ and $10 \%$ glycerol, for desalting. The protein content was determined according to Lowry et al. (1951).

Enzyme activity: Rubisco activity was evaluated in a coupled assay with 3-phosphoglycerate kinase (PGK) and glyceraldehyde-3-phosphate dehydrogenase (GADPH). The standard assay mixture contained $100 \mathrm{mM}$ Tris/HCl buffer (pH 8.0), $25 \mathrm{mMNaHCO}_{3}, 0.5 \mathrm{mM}$ ribulose, 1,5-bisphosphate (RuBP), $20 \mathrm{mM} \mathrm{MgCl}$, $3.5 \mathrm{mM}$ ATP, $0.25 \mathrm{mM}$ NADH, 80 nkat GAPDH and 80 nkat PGK, and appropriate amounts of purified Rubisco or crude enzyme extract. The enzyme was activated in the reaction medium at $25^{\circ} \mathrm{C}$ for $15 \mathrm{~min}$ prior to the RuBP addition. Rubisco activity was measured following the oxidation of NADH at $340 \mathrm{~nm}$.

Fluorescence measurements: Photosynthetic capacity was examined by measuring chlorophyll fluorescence with a Plant Efficiency Analyser (PEA). Induction kinetics of chlorophyll fluorescence were obtained from the upper leaf surface of control plants and plants submitted to salt treatment $(0.1 \mathrm{M} \mathrm{NaCl})$. Leaves were kept in darkness for 30 min before illumination for $3 \mathrm{sec}$ with a saturating irradiance (40\%). Various fluorescence parameters were measured $\left(\mathrm{F}_{\mathrm{o}}\right.$, $\left.\mathrm{F}_{\mathrm{m}}, \mathrm{F}_{\mathrm{v}}\right)$ and calculated $\left(\mathrm{F}_{\mathrm{v}} / \mathrm{F}_{\mathrm{m}}\right.$ and $\left.\mathrm{F}_{\mathrm{m}} / \mathrm{F}_{\mathrm{o}}\right)$. 
Chlorophyll: Chlorophyll content was determined according to Hiscox and Israelstam (1979). Leaf disks $\left(0.44 \mathrm{~cm}^{2}\right)$ were submerged in $2 \mathrm{~mL}$ of DMSO, incubated at $65^{\circ} \mathrm{C}$ for $2 \mathrm{~h}$ and the absorbance of the supernatant was read at 648 and $665 \mathrm{~nm}$. Chlorophyll content was calculated according to Arnon (1949).

Purification of Rubisco: Rubisco was purified from leaves of Vita 3, grown in control conditions (without $0.1 \mathrm{M} \mathrm{NaCl}$ ). After maceration of leaves $(1 \mathrm{~g})$ in $10 \mathrm{~mL}$ of extraction buffer (100 mM Mes/KOH, pH 6.5, 1 mM EDTA, $10 \mathrm{mM}$ DTT, $50 \%$ PVP-40 - w/v) with a chilled mortar and pestle, the homogenate was centrifuged at $40,000 g_{n}$ for $20 \mathrm{~min}$ and the supernatant submitted to ultracentrifugation at $100,000 g_{\mathrm{n}}$ for $1 \mathrm{~h}$. The clarified supernatant was treated with $\left(\mathrm{NH}_{4}\right)_{2} \mathrm{SO}_{4}$ to $40 \%$ saturation during $1 \mathrm{~h}$ and the precipitate removed by centrifugation at $40,000 g_{\mathrm{n}}$ for 10 min. The supernatant was treated further with $\left(\mathrm{NH}_{4}\right)_{2} \mathrm{SO}_{4}$ to $60 \%$ saturation. The precipitate obtained between 40-60\% saturation was collected by centrifugation, dissolved in 50 $\mathrm{mM}$ Tris/ $\mathrm{HCl}$ (pH 7.5) and layered on top of a continuous gradient of sucrose ranging from 0.2 to $0.8 \mathrm{M}$. The gradient was submitted to ultracentrifugation at $150,000 \mathrm{~g}$ for $5 \mathrm{~h}$. Fractions were collected in aliquots of $1 \mathrm{ml}$, read at 280 $\mathrm{nm}$ and submitted to native and SDS-polyacrylamide gel electrophoresis (SDS-PAGE).

Electrophoresis: Native electrophoresis was carried out according to Davis (1964), and the stacking and the main gels contained 4 and $7 \%$ of acrylamide, respectively. SDSPAGE was performed according to Laemmli (1970). Each sample was applied to the gel in a fixed amount of $20 \mu \mathrm{g}$. The concentration of acrylamide was $4 \%$ in the stacking gel and $12 \%$ in the main gel. The resolved polypeptides were visualized by staining the gel with Coomassie Blue G-250.

Preparation of the antibodies: Purified Rubisco was used for preparation of antibodies in mice. An aliquot of $17 \mu \mathrm{g}$ was injected subcutaneously in swiss mice, using the mineral oil marcol as adjuvant. A booster injection was given 21 days later and the serum collected 8 days after the booster injection. This serum was used for the immunological studies.

Ouchterlony and Immunoblotting: Crude leaf extracts and purified Rubisco were used in Ouchterlony (double immunodiffusion) and immunoblotting assays. The double immunodiffusion (Ouchterlony, 1949) was carried out in plates of $1 \%$ agarose and stained with Coomassie Blue R-250. After SDS-PAGE, the transfer of the proteins was carried out according to Towbin et al. (1979).

\section{RESULTS}

Growth parameters: Plants of both cultivars cultivated in the presence of $0.1 \mathrm{M} \mathrm{NaCl}$ showed a significant reduction in shoot length, leaf area and dry mass (figures 1 and 2, and table 1). The decrease was more accentuated for the Vita 5 cultivar which is considered to be more sensitive to salt stress.

Leaf photosynthetic properties: Salt stress did not affect either chlorophyll content (figure 3) or the fluorescence parameters measured in this work (table 2).

Rubisco activity: Vita 3 plants submitted to salt stress showed a $32 \%$ reduction in Rubisco activity whereas in Vita 5 the activity increased $43 \%$ (figure 4 ).

Table 1. Effect of salt treatment on the biomass of two cultivars (Vita 3 and Vita 5) of Vigna unguiculata. (Mean of five replicates, $\pm \mathrm{SE}$ )

\begin{tabular}{lccc}
\hline & & Control & $0.1 \mathrm{M} \mathrm{NaCl}$ \\
\hline & & Dry Weight $\left(\right.$ g.plant $\left.^{-1}\right)$ \\
\cline { 3 - 3 } Vita 3 & roots & $0.12 \pm 0.001$ & $0.10 \pm 0.030$ \\
& stems & $0.19 \pm 0.020$ & $0.11 \pm 0.020$ \\
& leaves & $0.50 \pm 0.100$ & $0.42 \pm 0.200$ \\
Vita 5 & roots & $0.08 \pm 0.03$ & $0.07 \pm 0.004$ \\
& stems & $0.18 \pm 0.050$ & $0.09 \pm 0.007$ \\
& leaves & $0.34 \pm 0.030$ & $0.20 \pm 0.030$ \\
\hline
\end{tabular}

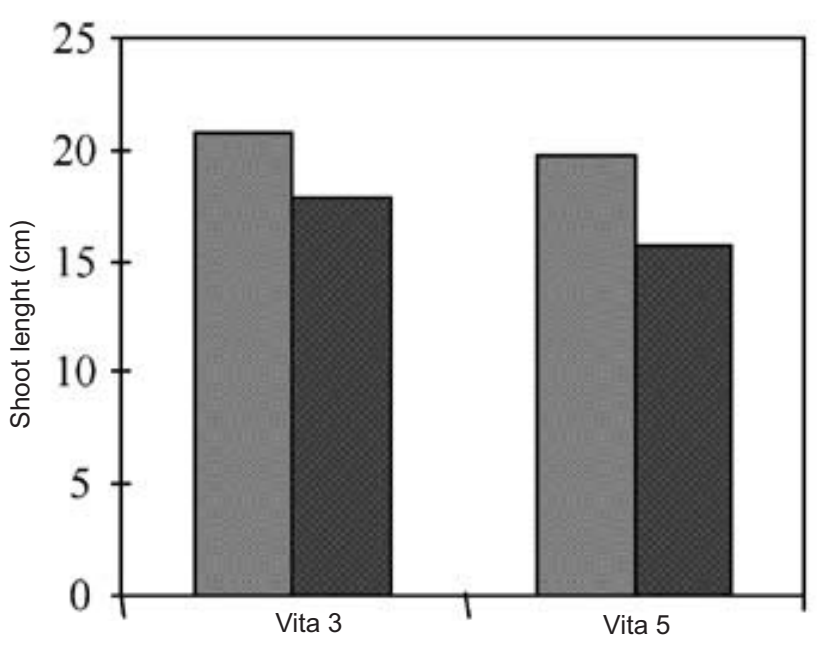

Figure 1. Salinity effect on shoot length of 2 cultivars of Vigna unguiculata (Vita 3 and Vita 5) grown in the absence ( $\square$ ) and presence of $0.1 \mathrm{M} \mathrm{NaCl}(\square)$. 


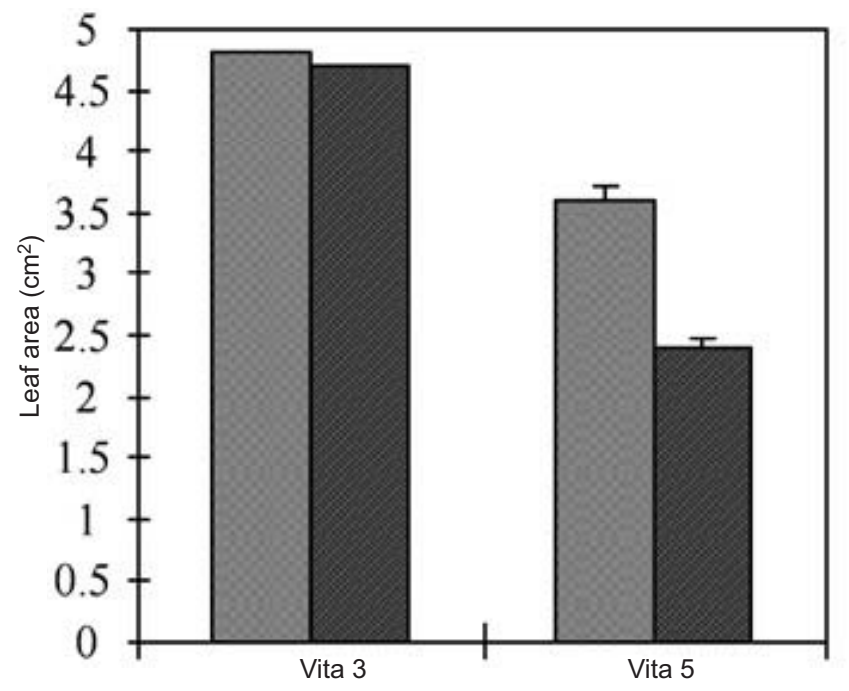

Figure 2. Leaf area of 2 cultivars of Vigna unguiculata (Vita 3 and Vita 5) grown in the absence ( $\square$ ) and presence of $0.1 \mathrm{M}$ $\mathrm{NaCl}(\square)$. Data are means $\pm \mathrm{SE}(\mathrm{n}=4-6)$.

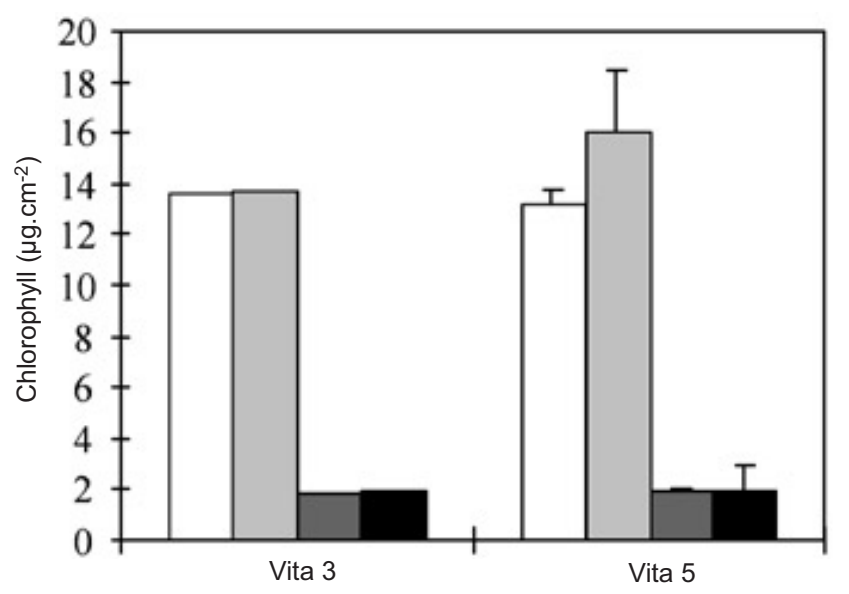

Figure 3. Chlorophyll contents $\left(\mu \mathrm{g} . \mathrm{cm}^{-2}\right.$ leaf area) from 2 cultivars of Vigna unguiculata (Vita 3 and Vita 5) grown in the absence ( $\square$ : chl. a; $\square$ chl. b) and presence of $0.1 \mathrm{M}$ $\mathrm{NaCl}(\square$ : chl. a; $\square$ chl. b). Data are means $\pm \mathrm{SE}(\mathrm{n}=4)$.
Electrophoresis: Purified Rubisco appeared as a single band of $\operatorname{Rf} 0.3$ when submitted to a native electrophoresis in $7 \%$ polyacrylamide gel (figure 5). When submitted to denaturing electrophoresis, a single band of $55 \mathrm{kDa}$ was detected.

Immunological analysis: Immunodiffusion (figure 6) demonstrated identity between the enzymes of the two plant cultivars, as well as between the plants grown in the absence and in the presence of salt. In order to determine if changes in enzyme activity correspond to changes in the amount of Rubisco in the extracts, an immunoblotting assay was carried out using the same amount $(20 \mu \mathrm{g} / \mathrm{lane})$ of protein extracts from the Vita 3 and Vita 5 cultivars. under control and salt conditions (figure 5). The immunoblots were scanned and quantified with a ScanImage software (Scion Corporation). The results revealed a decline in the amount of Rubisco in Vita 3 submitted to $0.1 \mathrm{M} \mathrm{NaCl}(15 \%)$ while an increase was observed for Vita $5(17 \%)$ under the same conditions.

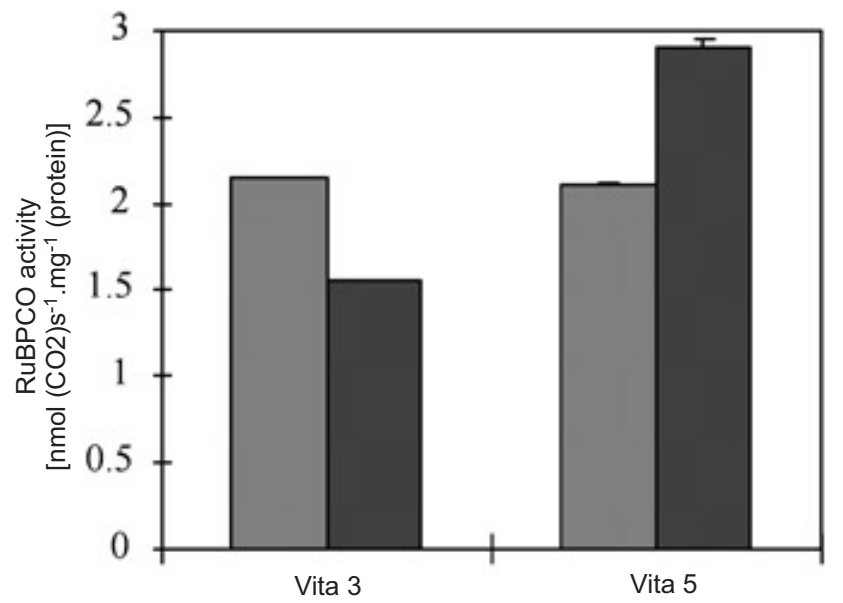

Figure 4. Changes in specific activity of Rubisco from 2 cultivars of Vigna unguiculata (Vita 3 and Vita 5) grown in the absence ( $\square)$ and presence of $0.1 \mathrm{M} \mathrm{NaCl}(\square)$. Data are means \pm SE $(n=3)$.

Table 2. Fluorescence parameters of Vigna unguiculata (Vita 3 and Vita 5) cultivars under control and salt conditions (0.1 M $\mathrm{NaCl}) . \mathrm{F}_{\mathrm{o}}$ - dark fluorescence level; $\mathrm{F}_{\mathrm{m}}$ - maximum fluorescence level; $\mathrm{F}_{\mathrm{v}}$ - variable fluorescence and RU - relative units. (Mean of five replicates $\pm \mathrm{SE}$ ).

\begin{tabular}{|c|c|c|c|c|c|c|}
\hline Cultivar & Treatment & $\begin{array}{l}\mathrm{F}_{\mathrm{o}} \\
\mathrm{RU}\end{array}$ & $\begin{array}{l}\mathrm{F}_{\mathrm{m}} \\
\mathrm{RU}\end{array}$ & $\begin{array}{l}\mathrm{F}_{\mathrm{v}} \\
\text { RU }\end{array}$ & $\begin{array}{c}\mathrm{F}_{\mathrm{v}} / \mathrm{F}_{\mathrm{m}} \\
\mathrm{RU}\end{array}$ & $\begin{array}{c}\mathrm{F}_{\mathrm{m}} / \mathrm{F}_{\mathrm{o}} \\
\mathrm{RU}\end{array}$ \\
\hline & Control & $1209 \pm 97$ & $2303 \pm 229$ & $1109 \pm 142$ & $0.47 \pm 0.014$ & $1.9 \pm 0.05$ \\
\hline Vita 3 & $0.1 \mathrm{M} \mathrm{NaCl}$ & $674 \pm 13$ & $3510 \pm 64$ & $2836 \pm 75$ & $0.81 \pm 0.007$ & $5.2 \pm 0.19$ \\
\hline & Control & $883 \pm 54$ & $2683 \pm 106$ & $1800 \pm 139$ & $0.67 \pm 0.03$ & $3.05 \pm 0.3$ \\
\hline Vita 5 & $0.1 \mathrm{M} \mathrm{NaCl}$ & $1394 \pm 276$ & $2210 \pm 85$ & $816 \pm 316$ & $0.37 \pm 0.14$ & $1.6 \pm 0.34$ \\
\hline
\end{tabular}




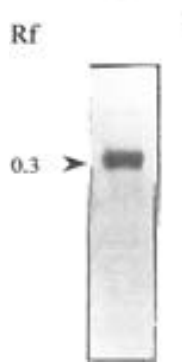

B

kDa

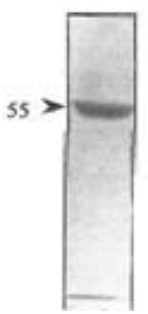

C

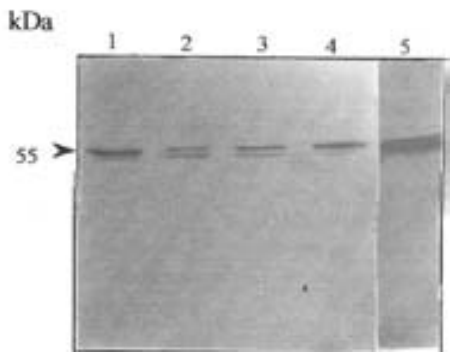

Figure 5. Protein patterns following native electrophoresis (A), - SDS-PAGE of purified Rubisco from Vita 3 (B), Rubisco protein level as determined by immunoblot analysis (C). Equal amounts of Rubisco protein $(20 \mu \mathrm{g})$ were loaded onto each lane: 1-Vita 3, control; 2-Vita 3, 0.1 $\mathrm{M} \mathrm{NaCl}$; 3-Vita 5, control; 4-Vita 5, $0.1 \mathrm{M} \mathrm{NaCl}$; 5-Purified Rubisco.

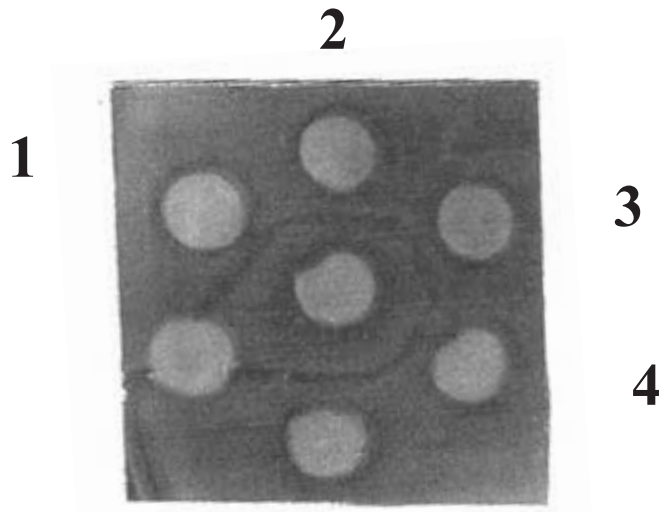

5

Figura 6. Ouchterlony double immunodiffusion. 1-Vita 5, control; 2-Vita 5, 0.1 M NaCl; 3- Vita 3, control; 4-Vita 3, $0.1 \mathrm{M} \mathrm{NaCl}$; 5-Purified Rubisco.

\section{DISCUSSION}

Rubisco from leaves of Vita 3 was purified to homogeneity, as demonstrated by native and SDS-PAGE electrophoresis. Purification of the enzyme was a major step in the execution of the present work, since it allowed the production of antibodies, which are indispensable tools for the understanding of the modifications undergone by the enzyme in the two cultivars under control and stressed conditions. Changes in growth parameters for Vita 3 and Vita 5 confirmed the stronger resistance of Vita 3 to salt stress. With regard to Rubisco activity, under salt stress conditions, contrasting results were observed for the two cultivars under salt stress conditions. While Vita 3 showed a decrease in Rubisco activity, increased activity was detected in Vita 5. These results were confirmed by immunoblotting.
Higher activity of key enzymes has been proposed as a strategy developed by some plants for survival under salt stress (Reuveni et al., 1990; Solomon et al., 1994; Aragão et al., 1997). Therefore, since Vita 3 demonstrates a better adaptation to salt conditions than Vita 5, it seems possible that other mechanisms are also triggered by salt stress in this cultivar.

Many environmental and external factors can affect photosynthetic rate either directly or indirectly. The measurements of fluorescence parameters (table 2) support the notion that the photosynthetic apparatus of both Vita 3 and Vita 5 was not significantly impaired by salt treatment. Increased $\mathrm{F}_{\mathrm{o}}$ (alterations in Photosystem II at the pigment level) accompanied by a decline in $\mathrm{F}_{\mathrm{v}}$ (variable fluorescence) could be caused by thylakoid damage, and a decrease of the $\mathrm{F}_{\mathrm{v}} / \mathrm{F}_{\mathrm{m}}$ ratio could indicate a decrease in net photosynthesis. Nevertheless, changes in chlorophyll fluorescence may occur before any physical signs of deterioration are evident. This could be the reason underlying the fact that Vita 3 and Vita 5 did not show modifications in chlorophyll contents.

Our data revealed that salt decreased the leaf area in Vita 5 suggesting it would have a lower capacity to absorb $\mathrm{CO}_{2}$. Therefore, although its Rubisco content increased, photosynthesis was reduced due a decrease capacity for $\mathrm{CO}_{2}$ absorption.

Several additional parameters have to be analyzed in order to clarify the differences in salt stress sensitivity of these two cultivars of $V$. unguiculata. Fernandes de Melo et al. (1994) showed that mitochondria of Vita 3 germinated under salt conditions presented higher ATPase activity than Vita 5 and that the alternative pathway of electron transport decreased in the most tolerant cultivar. With regard to Rubisco, it would be interesting to determine the nature of its activity modifications, such as, whether or not it was due to de novo synthesis.

\section{REFERENCES}

Aragão MEF, Jolivet Y, Silva Lima MG, Fernandes de Melo D, Dizengramel P (1997) NaCl-induced changes of NAD(P) malic enzyme activities in Eucalyptus citriodora leaves. Tree. 12: 66-72.

Arnon D (1949) Copper enzymes in chloroplasts polyphenol oxidase in Beta vulgaris. Plant Physiol. 65: 591-594

Davis BJ (1964) Disc electrophoresis. II Method and application to human serum proteins. Ann. New York Acad. Sci. 121: 404-427.

Desimone M, Henke A, Wagner E (1996) Oxidative stress induces partial degradation of the large subunit of ribulose1,5-biphosphate carboxylase/oxigenase in isolated chloroplast of barley. Plant Physiol. 111: 789-796. 
Downton WJS, Grant, WJR, Robinson, SP (1985) Photosynthetic and stomatal responses of spinach leaves to salt stress. Plant Physiol. 77: 85-88.

Fernandes de Melo D, Jolivet Y, Facanha AR, Gomes Filho E, Silva Lima MG, Dizengremel P (1994) Effect of salt stress on mitochondrial energy metabolism of Vigna unguiculata cultivars differing in $\mathrm{NaCl}$ tolerance. Plant Physiol. Biochemistry 32: 405-412.

Ferreira RMB, Teixeira, ARN (1992) Sulfur starvation in Lemna leads to degradation of ribulose-bisphosphate carboxylase without plant death. J. Biol. Chem. 267: 7253-7257.

Flowers TJ, Troke PF, Yeo AR (1977) The mechanism of tolerance in halophytes. Annu. Rev. Plant Physiol. Plant Mol. Biol. 28: 89-121.

Gimmler H, Kaaden R, Kirchner U, Weyand A (1984) The chloride sensitivity of Danaliella parva enzymes. Z. Pflanzenphysiol. 114:131-150.

Greenway H, Osmond CB (1972) Salt responses of enzymes from species differing in salt tolerance. Plant Physiol. 49: 256-259.

Guimarães CM (1988) Melhoramento e práticas culturais em caupi visando incrementar a resistência à seca. In: Araújo JPP, Watt, EE O caupi no Brasil, pp. 287-302 EMBRAPA (ed), Brasil.

Hiscox JD, Israelstam GF (1979) A method for the extraction of chlorophyll from leaf tissue without maceration. Can. J. Bot. 57:1332-1334.

Incharoensakdi A, Takabe T, Arakawa K (1986) Effet of betaine on enzyme activity and subunit interaction of ribulose-1,5-bisphosphate carboxilase/oxygenase from Aphanothece halophytica. Plant Physiol. 81:1044-1049.

Kaiser WM, Heber U (1981) Photosynthesis under osmotic stress. Effect of high solute concentration on the permeability of the chloroplast envelope and on the activity of stroma enzymes. Planta 153:423-429.
Keck RW, Boyer JS (1974) Chloroplast response to low leaf water potentials. III. Differing inhibition of electron transport and photophosphorylation. Plant Physiol. 67: 985-989.

Laemmli UK (1970) Cleavage of structural proteins during the assembly of the head of bacteriophage T4. Nature 227: 680-685.

Lowry OH, Rosebrough NJ, Farr AL, Randall RJ (1951) Protein measurement with the Folin phenol reagent. J. Biol. Chem. 193:265-275.

Ortiz-Lopez A, Ort DR, Boyer JS (1991) Photophosphorylation in attached leaves of Helianthus annuus at low water potentials. Plant Physiol. 96:1018-1025.

Ouchterlony O (1949) Antigen-antibody reactions in gels. Acta. Path. Microb. Scan. 26:507-515.

Reuveni M, Bennett AB, Bressan RA, Hasegawa PM (1990) Enhanced $\mathrm{H}+$ transport capacity and ATP hydrolysis activity of the tonoplast $\mathrm{H}+$-ATPase after $\mathrm{NaCl}$-adaptation. Plant Physiol. 94:524-530.

Seeman JR, Critchley C (1985) Effects of salt stress on the growth, ion content, stomatal behaviour and photosynthetic capacity of a salt-sensitive species. Phaseolus vulgaris L. Planta 164:151-162.

Solomon A, Beer S, Waisel Y, Jones GP, Paleg LG (1994) Effects of $\mathrm{NaCl}$ on the carboxylating activity of rubisco from Tamarix jordanis in the presence and absence of proline-related compatible solutes. Physiol. Plant. 90:198-204.

Towbin J, Staehelin T, Gordon J (1979) Electrophoretic transfer of proteins from polyacrylamide gels to nitrocellulose sheets: procedure and some applications. Proc. Natl. Acad. Sci. USA. 76:4350-4354.

Woodrow IE, Berry JA (1988) Enzymatic regulation of photosynthetic $\mathrm{CO}_{2}$ fixation in $\mathrm{C} 3$ plants. Annu. Rev. Plant Physiol. Plant Mol. Biol. 39:533-594. 